\title{
An Assessment of Antibiotic Resistant Bacteria in Poultry Litter and Agricultural Soils in Kandy District, Sri Lanka
}

\author{
E.M. Herath, A.G.K.N. Palansooriya, W.S. Dandeniya ${ }^{1 *}$, R.N. Jinadasa ${ }^{2}$ \\ Postgraduate Institute of Agriculture \\ University of Peradeniya \\ Sri Lanka
}

\begin{abstract}
Antibiotic resistant gut flora and nearly large amount of antimicrobials used in feed could end up in poultry litter. Hence, poultry litter could serve as sources of antibiotic resistance determinants to the environment. A study was conducted to assess the abundance of antibiotic resistant bacteria (ARB) in poultry litter and manure samples, and agricultural soils. Sampling was performed in WM3 agro-ecological region in Kandy district, Sri Lanka. Soil from thirteen cultivated and two uncultivated lands were sampled. Poultry litter from layer and broiler farms (four each) and poultry manure from five heaps at agricultural fields in the study area were collected. All samples were analyzed for $\mathrm{pH}$, electrical conductivity, respiration, potentially mineralizable $N(P M N)$, active carbon. Bacteria were enumerated using 0.3\% tryptic soy agar supplemented with tetracycline or enrofloxacin each at 0, 1 and 10 ppm in spread plate technique. Selected 20 isolates were characterized for gram staining and minimum inhibitory concentration (MIC) and minimum bactericidal concentration $(M B C)$ for tetracycline and antibiotic sensitivity towards tetracycline, enrofloxacin and neomycin. The highest and the lowest abundance of culturable bacteria populations were recorded for layer litter $\left(7.42 \pm 0.38 \log _{10} C F U / g\right)$ and cultivated soils (6.96 $\left.\pm 0.34 \quad \log _{10} \mathrm{CFU} / \mathrm{g}\right)$ respectively. Total Culturable bacteria populations significantly correlated with active $C$ and PMN of soils and manures. In soils, bacteria resistant towards tetracycline and enrofloxacins at 10 ppm ranged from 3.58 to $4.99 \log _{10}$ CFU/g and 0.96 to $2.55 \log _{10}$ CFU/g respectively. Abundance of bacteria resistant towards tetracycline was higher than enrofloxacin in all samples. MIC and MBC of the isolates ranged from 0.5 to $1024 \mathrm{ppm}$ and 4 to $>1024 \mathrm{ppm}$ of tetracycline, respectively. Poultry litter and manure, and soils collected from study area contain bacteria resistant to tetracycline and /or enroflaxacin. Variability in tetracycline and enrofloxacin resistance characters is suggestive of high diversity among ARB.
\end{abstract}

Keywords: Antibiotic resistance, Enrofloxacin, Poultry manure, Soil bacteria, Tetracycline

\section{INTRODUCTION}

Development and spread of antibiotic resistance in microbial communities has become a major health concern requiring unprecedented global coordination in antibiotic usage to avoid dire setbacks in medical and societal developments (Laxminarayan et al., 2013). This

\footnotetext{
1 Department of Soil Science,Faculty of Agriculture, University of Peradeniya, Sri Lanka

2 Faculty of Veterinary Medicine \& Animal Science, University of Peradeniya, Sri Lanka

* Corresponding author e-mail: warshisd@pdn.ac.lk
} 
is mainly because increased rates of antibiotic resistance development lowers the effectiveness of existing antimicrobial drugs in disease control, and forces the use of more strong and expensive broad spectrum antimicrobials (Laxminarayan et al., 2013). Antibiotics are low molecular weight microbial metabolites that can kill or inhibit the growth of sensitive bacteria and therefore, being used as primary tools for treating bacterial infectious diseases (Baharoglu et al., 2013). Growth promotion in farm animals via reducing immune system activity by administering antibiotics at a low concentration with feed was first discovered in the late 1940's (Boxall et al., 2003). Use of antibiotics as food additives for animal growth promotion has been banned in many countries including in Sri Lanka (De Silva, 2013).

Nearly 3 to $60 \%$ of antimicrobials used in feed could end up in poultry litter. Hence, litter could serve as a source of antibiotic resistance determinants to the environment (Diarrassouba et al., 2007). Antibiotic degradation rates in the environment vary and dependent upon environmental conditions such as temperature, $\mathrm{pH}$, composition of microbial community and their antibiotic resistance characters, chemical characters of the antibiotic, and the soil properties (Boxall et al., 2003; Kemper, 2008; NAAS, 2010). Residual antibiotics can affect soil microorganisms by imposing a selection pressure facilitating resistance development, inhibiting some microorganisms, and changing community composition (Popowska et al., 2012).

In Sri Lanka, poultry farmers widely use enrofloxacin, amoxicillin and tetracycline like antibiotics for therapeutic or sub-therapeutic measures. When one flock of broilers are sold at 42 days of age the bedding material in poultry pens are removed and handled differently (burnt, heaped and cured or directly sold to crop farmers) by farmers (Herath et al., 2014). Hence, the chemical and biological properties of freshly removed poultry litter and aged poultry litter, which is often referred to as poultry manure by crop farmers, could be different and contribute differently to spread antibiotic resistance to the environment (Hossain et al., 2010; Herath et al., 2014). Only two scientific communications provide evidence of presence of antibiotic resistant bacteria (ARB) in vegetable cultivated soils in Sri Lanka (Dandeniya et al., 2014; Mariaselvam and Rajapaksha, 2010). Information pertaining to natural background resistance of microbial communities in soil and ARB in poultry litter, manure and cultivated soils is lacking. The present study was conducted to assess whether poultry litter (bedding material) and manure can be serve as a source of ARB, and to assess the abundance and characteristics of ARB populations in poultry manure amended agricultural soils.

\section{MATERIALS AND METHOD}

\section{Site description and soil sampling}

Soil and manure were sampled from Gampola, Doluwa and Deltota areas in Mid Country Wet Zone (WM3) of Sri Lanka. A questionnaire was given to the poultry farmers and information was gathered about antibiotic usage in their farm, waste management, manure production and manure usage as a fertilizer. Thirteen cultivated fields in the middle slope and two fields with natural vegetation in upper slope position were selected for soil sampling. Soil samples were collected from $0-10 \mathrm{~cm}$ depth from thirteen random locations in each field and combined to make a composite sample representative of the field. In this article poultry manure refers to bedding material, which has been cured for more than one month after removal from the poultry pens, and used as manure in cultivation fields by 
farmers. Poultry litter refers to freshly removed bedding material from the pens of poultry farms. Poultry manure samples were collected from five manure piles located in agricultural fields and poultry litter samples were collected from four each medium scale layer and broiler farms. Soil, litter and manure samples were stored at $4^{0} \mathrm{C}$ until analyzed.

\section{Chemical properties of soils, litter and manure}

Electrical Conductivity (EC) and $\mathrm{pH}$ of air dried and sieved $(2 \mathrm{~mm}$ ) soil (soil to water at 1:2.5), and in fresh litter and manure samples (material to water at 1:5) were determined. Active carbon in samples was measured by potassium permanganate oxidizable carbon (POXC) method as described by Culman et al. (2012).

\section{Microbiological properties}

The microbial respiration rates in soil and manure samples was assessed by determining the $\mathrm{CO}_{2}$ evolution rate from samples over a 14 day incubation period using soda lime trap method (Anderson and Ingram, 1989). The potentially mineralizable nitrogen (PMN) was analyzed in fresh samples employing waterlogged incubation method as described by Keeney (1982).

Total culturable bacteria were enumerated using spread plate technique on $0.3 \%$ tryptic soy agar (TSA). A tenfold serial dilution in $1 \% \mathrm{NaCl}$ was used in the technique. Culture plates were incubated at $28^{\circ} \mathrm{C}$ for 48 hours and total number of bacterial colony forming units (CFU) and different types of colonies were counted. Bacteria resistant towards enrofloxacin and tetracycline was determined using $0.3 \%$ TSA medium spiked with each antibiotic at 1,5 , and $10 \mathrm{ppm}$ concentration (You et al., 2012). Selected colonies were sub-cultured on $0.3 \%$ TSA medium for isolation. Twenty bacteria isolates were used for gram staining and further characterization. Minimum inhibitory concentration (MIC) and minimum bactericidal concentration (MBC) of tetracycline for each isolate was determined as described previously (Andrews, 2001). Method in brief; antibiotic dilution range was prepared using $0.1 \%$ tryptic soy broth (dilution range: $0,0.25,0.5,1,2,4,8,16,32,64,128,256,512,750$, $1024 \mathrm{ppm})$. Each bacteria isolate was cultured in these dilution levels in triplicate at $28^{\circ} \mathrm{C}$ for 24 hours. The lowest concentration of antibiotics that inhibits the visible growth of bacteria was recorded as MIC. Results were verified by measuring the turbidity of the culture medium at $620 \mathrm{~nm}$ using spectrophotometer (SHIMADZU, UV-1601). Dilution levels did not result in a visible growth were plated on $0.3 \%$ TSA plates and the antimicrobial concentration where colony counts become zero was recorded as MBC for each isolate. For the identification of multiple antibiotic resistance traits of ARB isolates antibiotic susceptibility test (ABST) towards tetracycline $(30 \mu \mathrm{g})$, enrofloxacin $(5 \mu \mathrm{g})$ and neomycin $(30 \mu \mathrm{g})$ were performed using Muller Hinton Agar (Diarrassouba et al., 2007).

\section{Statistical analysis}

MINITAB (version 16) statistical software was used for statistical analysis. Analysis of variance (ANOVA) with GLM procedure was used to determine significance of sample type on measured parameters and Tukey's mean comparison was performed at $\mathrm{P}<0.05$. Pearsons's correlations were calculated for selected variables (MIC and MBC values, total culturable bacterial population and active $\mathrm{C}$, Respiration and $\mathrm{pH}, \mathrm{ARB}$ population). 


\section{RESULTS AND DISCUSSION}

According to the questionnaire survey all broiler and layer farmers in the study area used antibiotics as a sub-therapeutic measure. As indicated in the country report presented to the Animal Production and Health Commission for the Asia and Pacific (De Silva, 2013), the Veterinary Drug Control Authority of Sri Lanka has prohibited the use of antimicrobials in animal feed in 2013. Tetracycline, enrofloxacin and amoxicillin were the most common antibiotics used by farmers participated in the study. Most of the crop cultivators in the study area use poultry manure as a fertilizer because of its low cost and high availability. It was evident that farmers select type of poultry manure (origin of broiler/ layer) according to the crop they cultivate. Farmers participated in the study indicated the use broiler manure instead of layer manure when cultivate Manihot esculenta due to richness of rice hulls that resulting in higher ability to loosening soil than the layer manure. According to Boateng et al. (2006), soil bulk density is significantly decreased when apply poultry manure. All thirteen crop farmers used same procedure in poultry manure handling. They purchase poultry manure from a local supplier and arrange manure in a heap and allow aging for 1- 3 weeks. Later they mix soil to manure heap and let the manure age for another 1-2 weeks before applying to crops. Therefore, it is important to study the presence of ARB in freshly removed poultry litter and aged poultry manure separately. The chemical properties and population dynamics of ARB may change with aging of poultry litter as it has been observed with composting and with incubating under different temperatures or with herbaceous materials like the extracts of Azadiracta indica (Hossain et al., 2010; Herath et al., 2014).

Table 1. Total Culturable bacterial count (TE0) and total antibiotic resistant bacteria count towards 1 and $10 \mathrm{ppm}$ tetracycline (T1, T10) and enrofloxacin (E1, E10) in soils from two land use systems, poultry manure and litter from mid country wet zone of Sri Lanka.

\begin{tabular}{|c|c|c|c|c|c|}
\hline \multirow[b]{2}{*}{$\begin{array}{l}\text { Antibiotic } \\
\text { levels }\end{array}$} & \multicolumn{5}{|c|}{ Bacterial counts $\left(\log _{10}\right.$ CFU g ${ }^{-1}$ dry matter) } \\
\hline & TE0 & $\mathrm{T} 1$ & $\mathrm{~T} 10$ & E1 & E10 \\
\hline $\begin{array}{l}\text { Un cultivated } \\
\operatorname{soil}(n *=2)\end{array}$ & $7.25 \pm 0.7 \mathbf{a}$ & $4.34 \pm 0.39 \mathrm{c}$ & $4.15 \pm 0.47 \mathrm{c}$ & $2.63 \pm 0.61 \mathbf{b c}$ & $0.98 \pm 0.02 \mathbf{b}$ \\
\hline $\begin{array}{l}\text { Cultivated } \\
\text { soil(n=13) }\end{array}$ & $6.96 \pm 0.3 \mathbf{a}$ & $5.08 \pm 0.25 \mathbf{b}$ & $4.83 \pm 0.16 \mathbf{b}$ & $2.82 \pm 0.61 \mathbf{c}$ & $1.69 \pm 0.86 \mathbf{b}$ \\
\hline $\begin{array}{l}\text { Broiler } \\
\text { manure(n=5) }\end{array}$ & $7.14 \pm 0.3 \mathbf{a}$ & $5.04 \pm 0.18$ bc & $4.78 \pm 0.12 \mathbf{b}$ & $3.01 \pm 0.67 \mathbf{b c}$ & $1.77 \pm 0.9 \mathbf{a b}$ \\
\hline $\begin{array}{l}\text { Broiler } \\
\text { litter }(n=4)\end{array}$ & $6.73 \pm 0.5 \mathbf{a}$ & $5.26 \pm 0.67 \mathbf{b}$ & $4.26 \pm 0.46 \mathbf{c}$ & $3.75 \pm 0.17 \mathbf{a b}$ & $2.97 \pm 0.42 \mathbf{a}$ \\
\hline $\begin{array}{l}\text { Layer } \\
\text { litter(n=4) }\end{array}$ & $7.42 \pm 0.3 \mathbf{a}$ & $6.37 \pm 0.18 \mathbf{a}$ & $5.45 \pm 0.07 \mathbf{a}$ & $4.36 \pm 0.23 \mathbf{a}$ & $0.64 \pm 0.02 \mathbf{b}$ \\
\hline
\end{tabular}

Generally less than $10 \%$ of the population of soil microorganisms could be cultivated in artificial growth media and this component is called as culturable fraction (Stewart, 2012). The size of the bacteria population resistant towards tetracycline and enrofloxacin were significantly lower than the total culturable population. The sample type significantly affected the abundance of ARB (Table 1). Total culturable bacteria and ARB among environmental samples of this study were comparable and ranged from 0.64 to $7.42 \log$ CFU $\mathrm{g}^{-1}$ dry matter. The highest resistant populations for Enrofloxacin and Tetracycline at $1 \mathrm{ppm}$ 
and 10ppm were observed in animal-origin samples (Table 1). It ranged from 0.64 to 6.37 $\log$ CFU g ${ }^{-1}$ dry matter. Animal excretions are the major sources of antibiotic resistance determinants to poultry litter (Dissnayake, and Wijewardana, 2005). Microorganisms present in those animal excretions can grow well in the bedding material, which is rich in carbonaceous materials and nutrients and kept in the cage for nearly one year in the case of layer farms and 42 days in broiler farms (Wiedemann et al., 2008).

Results confirm the presence of ARB in soil, manure and litter samples. Previous studies also indicate considerable number of ARB could be expected in poultry waste (Kelley et al., 1998; Diarrassouba et al., 2007; Herath et al., 2014). When comparing five categories of samples the highest number of ARB were observed in layer litter followed by broiler litter (Table 1). It may be due to high selective pressure with high usage of antibiotics, and prolonged exposure to antibiotics, since bedding material in layer cages is renewed less frequently than in broiler farms. Results also indicate more bacteria were resistant towards tetracycline than to enrofloxacin $(\mathrm{p}<0.05)$. Nearly $40 \%$ of poultry farmers participated in the study have used enrofloxacin. The results are in the agreement with previous studies confirming there is a risk of spreading antibiotic resistance determinants to the environment when use poultry manure as a fertilizer (Dissnayake and Wijewardana, 2005; Diarrassouba et al., 2007; You et al., 2012).

The chemical and microbiological properties of environmental samples differed significantly $(p<0.05)$ (Table 2). Soil is a heterogeneous habitat and it has different ecological niches. Chemical, physical and biological properties of the environment affect the growth and activities of different bacteria (Nesme and Simone, 2015). In soil, total culturable bacterial population showed significant correlation with active $C(r=0.76), E C(r=0.56)$ and PMN $(r$ $=0.43$ ). In animal origin samples (poultry manure and litter data combined) total population of culturable bacteria significantly correlate with active $\mathrm{C}(\mathrm{r}=0.59), \mathrm{pH}(\mathrm{r}=-0.56)$, PMN ( $\mathrm{r}$ $=0.58)$ and respiration $(\mathrm{r}=0.61)$. Respiration significantly correlated with $\mathrm{pH}$ in both soil $(\mathrm{r}$ $=0.35)$ and manure $(\mathrm{r}=0.50)$ indicating the importance of $\mathrm{pH}$ on regulating the activity of soil microorganisms. Interestingly bacteria resistant towards $1 \mathrm{ppm}$ tetracycline and $1 \mathrm{ppm}$ enrofloxacin showed a significant positive correlation with $\mathrm{pH}(\mathrm{r}=0.516$ and $\mathrm{r}=0.70$ respectively). Since the $\mathrm{pH}$ of the environmental samples ranged from 4.39 to 9.39 , the portion of the bacteria population resistant towards $1 \mathrm{ppm}$ concentration of the studied antibiotics may be tolerant for stressful conditions in the environment. This needs further investigation.

As shown in Figure 1, population size of the culturable bacteria in soils and manure declined with increasing antibiotic concentration in the growth media $(r=-0.63)$. The ARB populations behave differently with different antibiotics (Popowska et al., 2012). In the present study enrofloxacin suppressed the bacteria population strongly compared to tetracycline (Figure 1). In crop fields soils are amended with poultry manure. Therefore, poultry manure might have introduced some ARB to cultivated soils (Popowska et al., 2012). Although present study indicate uncultivated soil had lesser ARB than the cultivated soils (Table 1 and Figure 1A), it is important to analyze more number of soil samples from uncultivated soils before drawing conclusions. The degree of suppression of bacteria population with increasing antibiotic concentration seems to be higher in uncultivated soil than agricultural soil or poultry manure (Figure 1) but this needs further investigation. 
Table 2. The Changes of chemical parameters in soil and poultry manure and litter from mid country wet zone of Sri Lanka.

\begin{tabular}{|c|c|c|c|c|c|}
\hline sample & pH & $\begin{array}{l}\text { EC } \\
\left.(\mu \mathrm{S} \mathrm{cm})^{-1}\right)\end{array}$ & $\begin{array}{c}\text { Active C } \\
\text { (mg POXC } \\
\mathrm{kg}^{-1} \text { soil) }\end{array}$ & $\begin{array}{c}\text { Potentially } \\
\text { mineralizable } \\
\text { Nitrogen } \\
\left(\mu \mathrm{g} \mathrm{N} \mathrm{g^{-1 }}\right. \\
\left.\text { week }^{-1}\right)\end{array}$ & $\begin{array}{c}\text { Respiration } \\
\text { (cumulative } \\
\mathrm{CO}_{2} \\
\text { emission } \mu \mathrm{g}^{-1} \text { week }^{-1} \text { ) }\end{array}$ \\
\hline \multirow{4}{*}{$\begin{array}{l}\text { Uncultivated } \\
\text { soil } \\
\text { Cultivated soil }\end{array}$} & 6.39 & 46 & 634 & 94,195 & 10,669 \\
\hline & $\pm 0.7 \mathbf{b c}$ & $\pm 18 \mathbf{d}$ & $\pm 35 \mathbf{a}$ & $\pm 44,489 \mathbf{a}$ & $\pm 2,322 \mathbf{a}$ \\
\hline & 5.83 & 56 & 392 & 97,423 & 620 \\
\hline & $\pm 0.5 \mathbf{c}$ & $\pm 21 \mathbf{d}$ & $\pm 80 \mathbf{b}$ & $\pm 22,888 \mathbf{a}$ & $\pm 101 \mathbf{b}$ \\
\hline \multirow[t]{2}{*}{ Broiler manure } & 7.72 & 1,787 & 663 & 153,108 & 12,004 \\
\hline & $\pm 1 \mathbf{a b}$ & $\pm 649 \mathbf{c}$ & $\pm 28 \mathbf{a}$ & $\pm 11,682 \mathbf{a}$ & $\pm 2,322 \mathbf{a}$ \\
\hline \multirow[t]{2}{*}{ Broiler litter } & 9.06 & 3,177 & NA & NA & 8,878 \\
\hline & $\pm 0.4 \mathbf{a}$ & $\pm 75 \mathbf{b}$ & & & $\pm 2,125 \mathbf{a}$ \\
\hline \multirow[t]{2}{*}{ Layer litter } & 8.93 & 3,980 & NA & NA & NA \\
\hline & $\pm 0.7 \mathbf{a}$ & $\pm 534 \mathbf{a}$ & & & \\
\hline
\end{tabular}

*NA- Not Analyzed

Values are given as mean \pm standard deviation. Mean in a given column followed by the same letter not significantly different $(\mathrm{p}<0.05)$

Fig. 1. The response of culturable antibiotic resistant bacteria in A)uncultivated soil (Uncul) and cultivated soil ( $\mathrm{Cul}$ ) and $\mathrm{B}$ ) in broiler manure (Man) to the tetracycline (t) and enrofloxacin (e) concentration in grow the medium(Tryptic soy agar).

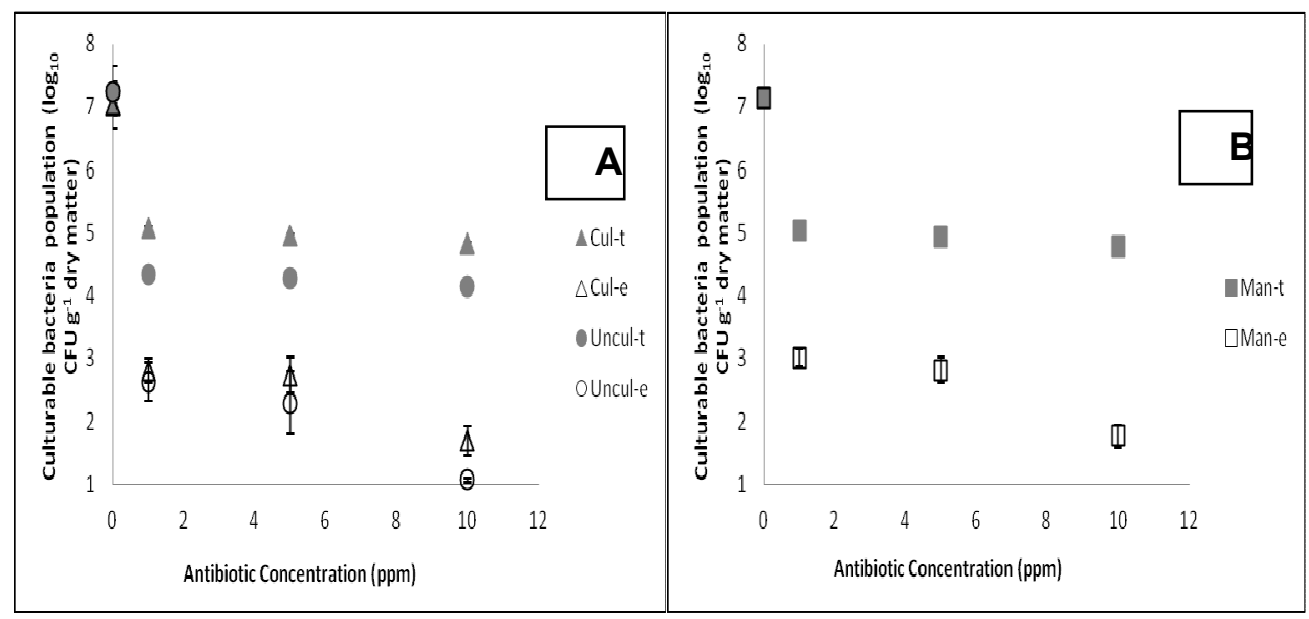

Twenty ARB isolates were isolated from poultry samples and were tested for Gram staining, MIC, MBC and ABST. Selected isolates showed diverse characteristics. Thirteen out of twenty were gram negative while others were positive. As revealed in the ABST performed following the National Committee for Clinical Laboratory Standards, eleven isolate were resistant to tetracycline $(30 \mu \mathrm{g})$ and two isolate were intermediately resistant to tetracycline, five isolate were resistant to enrofloxacin $(5 \mu \mathrm{g})$. There were five isolates that were resistant to neomycin $(30 \mu \mathrm{g})$. Majority of the isolates were resistant to tetracycline only. Four out of twenty isolates exhibited multiple antibiotic resistant and these four had high level of MIC and MBC than other bacterial isolates. 
Bacterial MIC is the lowest concentration of an antibiotic that will inhibit the growth of bacteria after overnight incubation in a broth medium. It is used to determine the susceptibility of organism towards a particular antibiotic (Andrews, 2001). The ARB isolates obtained from soil and manure samples had different MIC values with five isolates showing $128 \mu \mathrm{g} \mathrm{ml}^{-1}$ and one with $1024 \mu \mathrm{g} \mathrm{ml}^{-1}$ of tetracycline. Majority of isolates showed MIC of tetracycline greater than $32 \mu \mathrm{g} \mathrm{ml}^{-1}$. Minimum bacteriacidal concentration (MBC) in bacteria is the lowest concentration of antibiotic which completely prevent the growth of bacteria. Therefore it is useful to observe germ killing activity of an organism (Andrews, 2001). The MIC and MBC values of the bacterial isolates used in this study correlated significantly $(\mathrm{r}=0.677)$ (Figure 2). Majority of ARB isolates showed $\mathrm{MBC}$ level $>256 \mu \mathrm{g} \mathrm{ml}^{-1}$ of tetracycline. Therefore, these isolated could survive in high level of antibiotic concentration levels. Presence of bacteria resistant to $100 \mathrm{ppm}$ tetracycline in poultry manure in Sri Lanka has been reported previously (Herath et al., 2014). MIC and MBC of tetracycline in the ranges of 20 to $180 \mu \mathrm{g} \mathrm{ml}^{-1}$ and 30 to $300 \mu \mathrm{g} \mathrm{ml}^{-1}$, respectively, have been reported by Popowska et al. (2012) for bacteria isolates obtained from agricultural soils treated with poultry manure. Spreading of ARB with higher MIC and MBC values in the environment is a threat for public health (Laxminarayanv et al., 2013; Popowska et al., 2012). The reason for existence of innate resistance towards an antibiotic is a permanent genetically determined character of a bacterial species (Popowska et al., 2010). Bacteria have different mechanisms to resist antibiotics (Nesme and Simone, 2015) hence, a large diversity could be expected among studied ARB populations.

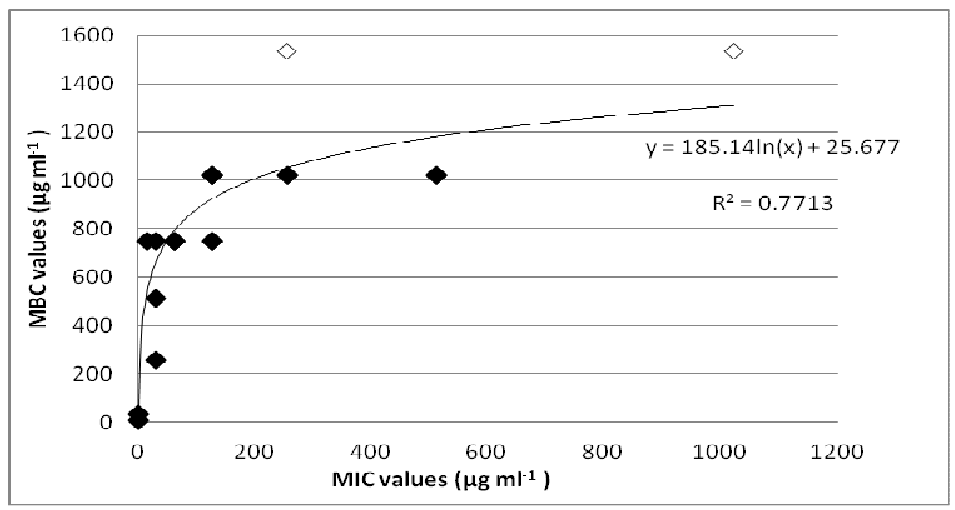

Fig. 2. Minimum inhibitory concentration (MIC) and minimum bactericidal concentration (MBC) of tetracycline for selected bacterial isolates obtained form poultry manure and soil samples. Open symbols in the figure represent the cultures which have mulitple drug resistant.

In Sri Lanka only two scientific communications are available on ARB in soil (Dandeniya et al., 2014; Mariaselvam and Rajapaksha, 2010), which have been presented in scientific proceedings. Therefore, the present study is the first providing the abundance and the nature of resistance of ARB in Sri Lankan agricultural soils and poultry litter and manure samples. Although poultry manure is a popular fertilizer among farmers only few studies have been conducted locally to test whether poultry litter could act as a carrier for antimicrobials and antibiotic resistant organisms (Dissnayake and Wijewardana, 2005; Karunarathna et al., 2012; Herath et al, 2014). But the difference in ARB in poultry litter in comparison to manure has not been addressed in these previous reports. Therefore, present study provides 
insightful information on the nature of antibiotic resistance of bacteria and their diversity in soil and in two different poultry litter types and poultry manure.

\section{CONCLUSIONS}

Poultry manure, litter and soil collected from WM3 agro-ecological region in Kandy district harbor bacteria resistant towards tetracycline and enroflaxacin, which were the commonly used antibiotics by medium scale poultry farmers in the study area. Recovery of antibiotic resistant populations in soils and manure declined with increasing antibiotic concentration in the growth medium. The MIC and MBC of tetracycline for the isolates ranged from 0.5 to $1024 \mu \mathrm{g} \mathrm{ml}^{-1}$ and 4 to $>1024 \mu \mathrm{g} \mathrm{ml}^{-1}$, respectively. These results suggest there is a high diversity among antibiotic resistance bacteria in soil, and poultry manure and litter.

\section{ACKNOWLEDGEMENT}

Authors acknowledge the financial assistance provided from International Foundation for Science (IFS C-5268 grant).

\section{REFERENCES}

Andrews, J.M. (2001). Determination of minimum inhibitory concentrations. Journal of antimicrobial Chemotherapy. 48(1), 5 - 16.

Anderson, J.M. and Ingram, J.S. (1989). Tropical soil biology and fertility. A Handbook of methods, C.A.B. International.

Baharoglu, Z., Garriss, G. and Mazel, D. (2013). Multiple pathways of genome plasticity leading to development of antibiotic resistance. Antibiotics. 2, 288 - 315.

Boateng, S.A., Zickermann, J. and Kornahrens, M. (2006). Poultry manure effect on growth and yield of maize. West Africa Journal of Applied Ecology. 9, 1 - 11.

Boxall, A.B., Kolpin, D.W., Halling-Sørensen, B., and Tolls, J. (2003). Peer reviewed: Are veterinary medicines causing environmental risks?. Environmental Science \& Technology. 37, 286 - 294.

Culman, S.W., Snapp, S.S. and Freeman, M.A. (2012). Permanganate oxidizable carbon reflects a processed soil fraction that is sensitive to management. Soil Science Society of America. 76, 494 - 504.

Dandeniya, W., Herath, E.M., Samarasinghe, A.G.S.I. and Jinadasa, R.N. (2014). Effect of veterinary antibiotics on soil microorganisms inhabiting intensively cultivated ultisol. Proceedings of the International Conference on One Health: 6.

De Silva, W.K. (2013). Country report, Sri Lanka. In: Report of the 37th session of the Animal Production and Health Commission for Asia and the Pacific. FAO, Thimphu, Bhutan. 22-26 September 2013. 128 - 130. 
Diarrassouba, F., Diarra, M.S., Bach, S., Delaquis, P., Pritchard, J., Topp, E. and Skura, B.J. (2007). Antibiotic resistance and virulence genes in commensal Escherichia coli and Salmonella isolates from commercial broiler chicken farms. Journal of Food Protection. 70, 1316 - 1327.

Dissnayake, D.R.A. and Wijewardana, T.G. (2005). Indigenous chickens as sentinels for antimicrobial resistance to Escherichia coli in Sri Lanka. Proceedings of the Peradeniya University Research Sessions.

Herath, E.M., Dandeniya, W.S., Samarasinghe, A.G.S.I., Bandara, T.P.M.S.D. and Jinadasa, R.N. (2014). A Preliminary investigation on methods of reducing antibiotic resistant bacteria in broiler litter in selected farms in mid country, Sri Lanka. Tropical Agricultural Research. 26(2), 409 - 414.

Hossain, A.T.M.S., Rahman, F., Saha, P.K. and Solaiman, A.R.M. (2010). Effects of different aged poultry litter on the yield and nutrient balance in boro rice cultivation. Bangladesh Journal of Agricultural Research. 35(3), 497 - 505.

Karunarathna, K.G.R.N., Arulkanthan, A. and Jayasena, N.U.A. (2012). Antimicrobial resistance patterns in Escherichia coli of poultry origin in the Kandy district. Proceedings of the Peradeniya University Research Sessions. 17.

Kelley, T.R., Pancorbo, C., Merka, C. and Barnhart, M. (1998). Antibiotic resistance of bacterial litter isolates. Poultry Science. 77, 243 - 247.

Keeney, D.R. and Bremner, J.M. (1996). Comparison and evaluation of laboratory methods of obtaining an index of soil nitrogen availability. Agronomy Journal. 58, 498 - 503.

Kemper, N. (2008). Veterinary antibiotics in the aquatic and terrestrial environment. Ecological Indicators. 8, 1 - 13 .

Laxminarayan, R., Duse, A., Wattal, C., Zaidi, A.K., Wertheim, H.F., Sumpradit, N. and Cars, O. (2013). Antibiotic resistance-the need for global solutions. The Lancet infectious diseases. 13(12)P, $1057-1098$.

Popowska, M., Miernik, A., Rzeczycka, M. and Lopaciuk, A. (2010). The impact of environmental contamination with antibiotics on levels of resistance in soil bacteria. Journal of Environmental Quality. 39, 1679 - 1687.

Mariaselvam, A.A. and Rajapaksha. R.M.C.P. (2010). Antibiotic and metal resistant bacteria in manure amended soils of two distinct vegetable cropping systems in the up country of Sri Lanka. Peradeniya University Research Sessions. 15, 260 - 262.

National Academy of Agriculture Sciences. (2010). Antibiotics in manure and soil - a grave threat to human and animal health. Policy Paper No.43.

Nesme, J. and Simone, P. (2015). The soil resistome: a critical review on antibiotic resistance origins, ecology and dissemination potential in telluric bacteria. Environmental Microbiology. 17(4), 913 - 930. 
Popowska, M., Rzeczycka, M., Miernik, A., Krawczyk-Balska, A., Walsh, F. and Duffy, B. (2012). Influence of soil use on prevalence of tetracycline, streptomycin, and erythromycin resistance and associated resistance genes. Antimicrobial Agents and Chemotherapy. 56(3), 1434.

Stewart,.E.J. (2012). Growing unculturable bacteria. Journal of Bacteriology. 194(16), 4151 $-4160$.

Wiedemann, S.G., McGahan, E.J. and Burger, M. (2008). Layer hen manure analysis report. Australian egg corporation limited manure analysis. 1448 - 1316.

You, Y., Hilpert, M. and Ward. M.J. (2012). Detection of a common and persistent tet chicken-waste-impacted farm soil. Applied Environmental Microbiology. 78(9), 3203. 